\title{
P95 - Cow's milk allergy with tolerance to sterilised cow's milk. A case report
}

\author{
Liseth Villafana ${ }^{1 *}$, Soledad Terrados ${ }^{1}$, Amalia Ledesma $^{2}$ \\ From 3rd Pediatric Allergy and Asthma Meeting (PAAM) \\ Athens, Greece. 17-19 October 2013
}

\section{Introduction}

Allergy to cow's milk (CM) proteins has as major allergens caseins (60\%), $\beta$-lactoglobulin (9\%) and $\alpha$-lactalbumin (4\%). Thermal processes for milk industrialization include: pasteurization (low: $63^{\circ} \mathrm{C}$ for $30 \mathrm{~min}$ or High: $72{ }^{\circ} \mathrm{C}$ for 15 seconds), UHT heating $\left(145^{\circ} \mathrm{C}\right.$ for $\left.1-2 \mathrm{~s}\right)$ and sterilization $\left(115^{\circ} \mathrm{C}\right.$ for $\left.15 \mathrm{~min}\right)$. It's accepted that these processes denature milk proteins in different proportions without having an effect on antigenicity or allergenicity.

\section{Case report}

A 2 years old boy, exclusively breastfed up to 3 months and then fed with adapted infant formula with good tolerance until 18 months. Referred by his pediatrician with suspected CM allergy because of immediate perioral erythema and pruritus after consumption of milk and some dairy products (yoghurt) during the 2 last months. However, he tolerates a sterilized cow's milk and cheese. He hadn't got any concomitant systemic symptoms like dyspnea, vomiting, or diarrhea. Skin test were performed: CM (5mm), $\alpha$-lactalbumin (24mm), $\beta$-lactoglobulin $(11 \mathrm{~mm})$, casein $(20 \mathrm{~mm})$, sterilized milk $(\mathrm{SM})(3 \mathrm{~mm})$, pasteurized milk(PM) $(11 \mathrm{~mm})$, UHT milk $(\mathrm{UM})(9 \mathrm{~mm})$. Histamine $(6 \mathrm{~mm})$ and Saline $(0 \mathrm{~mm})$. Provocation test with yoghurt: Positive (cervicofacial urticaria).

SM, PM and UM extracts were analysed using SDSPAGE and immunoblooting with patient's serum and with a pool of sera from CM allergic patients. Patient's serum recognized a band of about $13 \mathrm{kDa}$ (molecular weight described for the alpha-lactalbumin $(14 \mathrm{kDa})$ in the UM and PM, but not in sterilized milk.

\section{Comments}

The patient has a primary sensitization to $\alpha$-lactalbumin protein fraction of cow's milk. According to our study,

${ }^{1}$ Ramón y Cajal Hospital, Madrid, Spain

Full list of author information is available at the end of the article this fraction is not recognized by the patient in sterilized milk so we conclude that, in contrast to the accepted, this method of treatment do alters the structure of at least this fraction of the milk which decreasing its allergenicity. We cannot demonstrate this with other industrial processes.

Authors' details

${ }^{1}$ Ramón y Cajal Hospital, Madrid, Spain. ${ }^{2}$ ALK- Albelló Spain, Madrid, Spain.

Published: 28 February 2014

doi:10.1186/2045-7022-4-S1-P150

Cite this article as: Villafana et al:: P95 - Cow's milk allergy with tolerance to sterilised cow's milk. A case report. Clinical and Translational Allergy 2014 4(Suppl 1):P150.
Submit your next manuscript to BioMed Central and take full advantage of:

- Convenient online submission

- Thorough peer review

- No space constraints or color figure charges

- Immediate publication on acceptance

- Inclusion in PubMed, CAS, Scopus and Google Scholar

- Research which is freely available for redistribution

Submit your manuscript at www.biomedcentral.com/submit
C Biomed Central 